\title{
Studi Pendahuluan Untuk Pengembangan Indeks Kesiapan Kerja Harian
}

\author{
Yusuf Nugroho Doyo Yekti * \\ Program Studi Teknik Industri, Fakultas Rekayasa Industri, Telkom University, Jl. Telekomunikasi No. 01, Terusan Buah \\ Batu, Sukapura, Dayeuhkolot, Bandung, Jawa Barat, 40257, Indonesia
}

\section{ARTICLE INFORMATION}

Article history:

Received: April 24, 2018

Revised: July 18, 2018

Accepted: July 23, 2018

Kata Kunci:

Indeks Kesiapan Kerja Harian

Kecelakaan Kerja

Psychomotor Vigilance Task

\section{A B S T R A K}

Kecelakaan kerja merupakan masalah yang perlu diperhatikan dengan serius. Jumlah kecelakaan kerja semakin bertambah, dan tingkat kematian sangat tinggi di Indonesia. Penelitian ini bertujuan untuk mengembangkan indeks kesiapan kerja sebagai ukuran untuk memastikan bahwa semua pekerja berada dalam kondisi bugar, sehingga mampu bekerja secara efektif dan aman. Studi literatur telah dilakukan melalui beberapa tahap, yaitu 1) penentuan stategi pencarian dan proses pencarian pustaka, 2) penetapan kriteria terhadap pustaka yang akan dimasukkan dan yang akan dikeluarkan 3) pengukuran kualitas pustaka, dan 4) penarikan kesimpulan. Eksperimen dijalankan dengan melibatkan empat orang, yang bekerja pada malam hari dan pagi hari. Hal yang diukur dalam eksperimen antara lain total waktu tidur, denyut jantung ketika istirahat, waktu reaksi dengan teknik PVT (Psychomotor Vigilance Task) serta berat badan. Hasil penelitian adalah persamaan untuk mengukur indeks kesiapan kerja harian dengan mempertimbangkan tiga faktor, yaitu faktor kecukupan tidur, faktor gangguan siklus sirkadian, dan faktor individu. Indeks kesiapan kerja harian telah dikembangkan dalam suatu persamaan matematis. Nilai indeks tersebut memiliki korelasi yang kuat dengan pengukuran kesiapan kerja secara subyektif. Hal tersebut menunjukkan bahwa pengukuran indeks kesiapan kerja harian dapat dipercaya karena memiliki kemiripan dengan perasaan kesiapan kerja yang dirasakan oleh pekerja.

\section{A B S T R A C T}

Work related accident is a problem that needs to be considered seriously in Indonesia. The number of occupational accidents is increasing significantly from 96,314 in 2009 to 110,285 in 2015 . The mortality rate in these cases is very high. This research aims to develop a daily fitness for duty index as a measurement to ensure that workers are able to work effectively and safely. Systematic literature review had been carried out through several stages, i.e. 1) determination of searching strategy, and searching process, 2) determination of searching criteria, 3) quality control for literature, and 4) conclusion. The experiment involved four participants. They divided into two groups: night shift workers and morning shift workers. Total sleep time, heart rate at rest, reaction time, and body weight were recorded during the experiment. The daily fitness for duty index has been developed that consider sleep sufficiency factor, circadian cycle misalignment factor, and individual factor. The daily fitness for duty index has a strong correlation with subjective work readiness measurement. Therefore, it can be concluded that the daily fitness for duty index is trustworthy to measure fitness for duty.

\section{PENDAHULUAN}

Kecelakaan kerja merupakan masalah yang belum terselesaikan di Indonesia. Jumlah kecelakaan kerja semakin bertambah dari tahun 2009 hingga tahun 2015, seperti terlihat pada Gambar 1. Peningkatan jumlah kenaikan kecelakaan kerja rata-rata pertahun adalah 2,3\% [1], [2]. Pola kenaikan jumlah kecelakaan kerja dipercaya akan semakin bertambah buruk pada tahun berikutnya, jika tidak terdapat perubahan cara berpikir dalam penanggulangan kecelakaan kerja. 
Tingkat kematian pekerja di Indonesia lebih tinggi jika dibandingkan dengan negara-negara sekitar, seperti Singapura, Filipina, Malaysia, dan Thailand. Pada tahun 2011, data BPJS menunjukkan bahwa tingkat kematian pekerja (fatality rate) di Indonesia adalah 21,6. Hal ini berarti terdapat 21 pekerja, dalam populasi 100.000 pekerja, telah meninggal dunia akibat kecelakaan kerja. Perbandingan tingkat kematian pekerja dapat dilihat pada Gambar 2 [1], [3]. Permasalahan kecelakaan kerja perlu ditanggulangi sesegera mungkin, dengan tujuan untuk meningkatkan daya saing industri, serta memberikan perlindungan bagi pekerja terhadap risiko kecelakaan kerja.

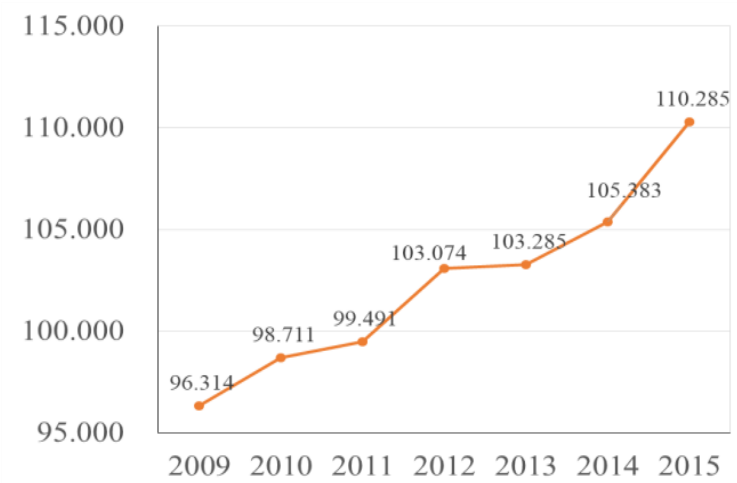

Gambar 1. Angka Kecelakaan kerja di Indonesia tahun 2009-2015

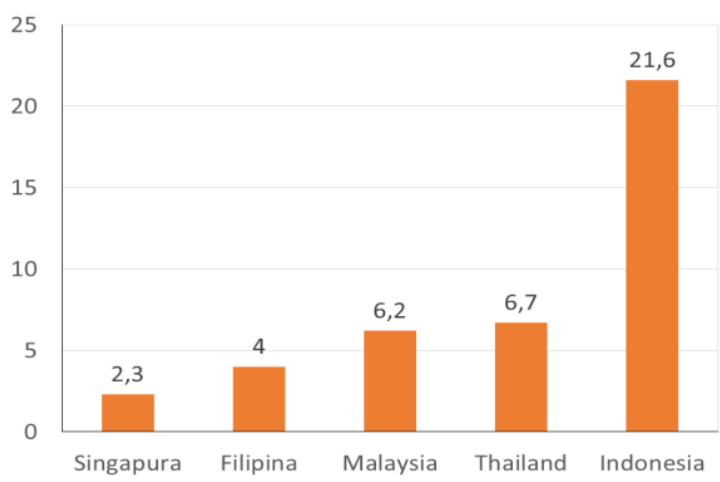

Gambar 2. Tingkat kematian tiap 100.000 pekerja pada tahun 2011

Faktor manusia adalah faktor yang dominan dalam kecelakaan kerja [4]. Sekitar 80\% [5], $85 \%-90 \%$ [6], atau $88 \%$ [7] kecelakaan kerja disebabkan oleh faktor yang terkait dengan manusia. Banyak penelitian terdahulu yang menunjukkan bahwa faktor manusia merupakan faktor dominan yang berkonstribusi terhadap kecelakaan kerja.
Salah satu faktor manusia yang terkait dengan kecelakaan kerja adalah kesiapan kerja. Kesiapan kerja dapat diartikan sebagai kondisi fisik dan mental pekerja, yang memungkinan untuk menyelesaikan tugas yang diberikan oleh pemberi kerja secara sehat dan aman, tidak membahayakan diri sendiri, sesama pekerja, masyarakat sekitar, dan tidak merusak properti perusahaan [8], [9]. Kesiapan kerja berguna untuk mendeteksi risiko kecelakaan kerja, terutama pada kondisi yang diketahui muncul aspek-aspek yang terkait kelelahan kerja, seperti aspek gangguan tidur, aspek waktu terjaga, dan aspek siklus sirkadian [10].

Kesiapan kerja perlu diukur untuk memastikan seluruh pekerja berada dalam kondisi bugar untuk melaksanakan tugas secara efektif, dan tidak melakukan aktivitas yang berbahaya bagi diri sendiri dan masyarakat sekitar [11], [12]. Pengukuran kesiapan kerja dapat membantu pekerja untuk memperhatikan kesehatan dirinya sendiri, mendeteksi dan memperbaiki kondisi kerja, serta menghimpun data yang terkait dengan kondisi pekerja [13]. Kesiapan kerja diukur ketika penerimaan pekerja baru, penempatan pekerja baru, ketika kembali bekerja setelah sakit dalam jangka waktu yang lama, adanya perilaku pekerja yang tidak normal, adanya perhatian pekerja terhadap kondisi kesiapan kerja diri sendiri, adanya laporan dari sesama pekerja mengenai kesehatan fisik dan kesehatan mental pada pekerja lain, adanya masalah kesehatan kerja yang menyebabkan penurunan kinerja, adanya perubahan sistem kerja yang signifikan, adanya suatu kebutuhan untuk memantau kondisi pekerja secara periodik [13], [14]. Perusahaan memiliki tanggung jawab untuk menghindari risiko kecelakaan dan penyakit akibat kerja yang ditimbulkan oleh pekerja yang berada dalam kondisi tidak bugar [14]. Pekerja yang tidak bugar dianggap sebagai salah satu sumber bahaya yang harus diwaspadai [15].

Faktor-faktor yang terkait dengan kesiapan kerja belum diketahui dengan baku. Beberapa literatur menyebutkan adanya perbedaan pada faktorfaktor yang berpengaruh terhadap kesiapan kerja. Kesiapan kerja ditentukan dari faktor kondisi kesehatan, kemampuan fisik, dan kapasitas 
fungsional pekerja [16]. Kesiapan kerja merupakan kesesuaian antara kemampuan fisik dan tuntutan kerja fisik [13]. Perbedaan pendapat tersebut mengakibatkan belum adanya suatu indeks yang dapat mengukur kesiapan kerja secara praktis dan obyektif. Teknik pengukuran kesiapan kerja sebenarnya sudah ada, misalnya pemberian sertifikat kesiapan kerja setelah pemeriksaan medis [17], pemeriksaan keseimbangan tubuh [18], atau fatigue calculator yang membutuhkan data waktu tidur ketika 48 jam sebelum kerja [19]. Namun, pengukuran tersebut diyakini kurang praktis, karena membutuhkan peralatan khusus, dan membutuhkan waktu pemeriksaan yang cukup lama.

Penelitian ini berfokus pada upaya pengembangan indeks kesiapan kerja sebagai ukuran untuk memastikan bahwa semua pekerja berada dalam kondisi bugar setiap hari, sehingga mampu bekerja secara efektif dan tidak melakukan perbuatan yang mengancam keselamatan diri sendiri dan publik. Indeks ini dapat bermanfaat untuk mendeteksi pekerja yang layak bekerja atau tidak layak bekerja.

\section{METODE PENELITIAN}

Peneliti melakukan studi literatur secara sistematis dengan tata cara yang mengacu pada artikel dari Espita dkk [20]. Langkahlangkah studi literatur tersebut terdiri dari: 1) penentuan stategi pencarian dan proses pencarian pustaka, 2) penetapan kriteria terhadap pustaka yang akan dimasukkan dan yang akan dikeluarkan; 3) pengukuran kualitas pustaka, dan 4) penarikan kesimpulan terhadap data yang didapatkan.

Penelitian dilanjutkan dengan eksperimen yang melibatkan empat orang responden berjenis kelamin laki-laki. Responden dipilih secara random, yang terdiri dari dua orang pekerja shift malam, dan dua orang yang bekerja di pagi hari. Semua partisipan memiliki berat tubuh diatas 70 kilogram. Usia Partisipan berkisar antara 26 hingga 38 tahun.

Hasil penelitian ini tidak dimaksudkan untuk dijadikan generalisasi untuk populasi umum. Hasil penelitian ini berupa faktor-faktor relevan yang berkonstribusi pada kesiapan kerja, sehingga dapat mereduksi variabel-variabel yang tidak relevan untuk digunakan dalam eksperimen lanjutan, dengan jumlah partisipan yang lebih banyak. Meskipun demikian, hasil penelitian ini memberikan gambaran awal yang jelas, mengenai konsep pengukuran kesiapan kerja harian.

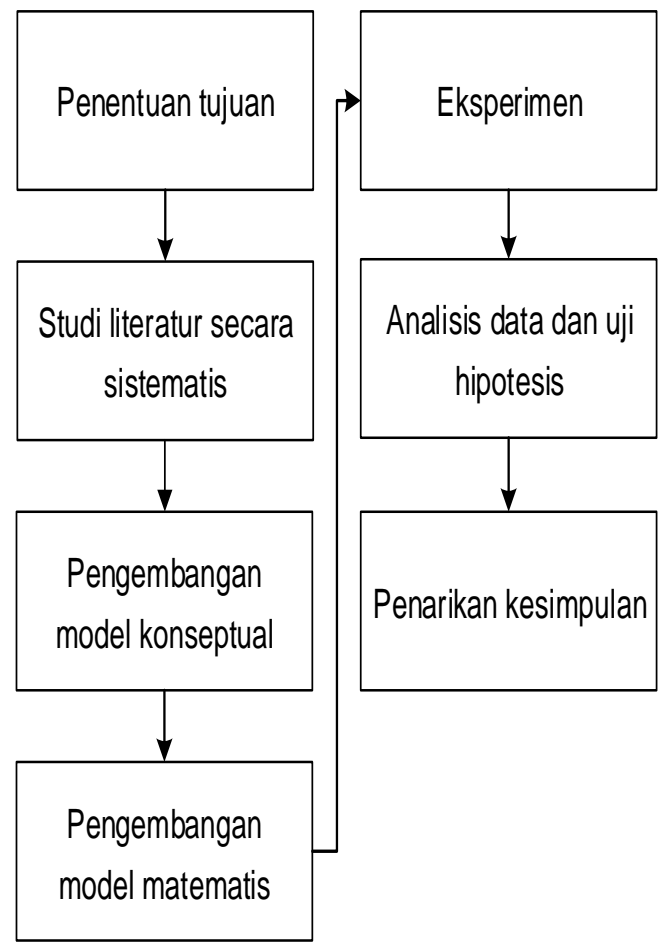

Gambar 3. Langkah-langkah penelitian

Data dianalisis dengan cara membandingkan pengukuran kesiapan kerja harian secara obyektif dengan pengukuran kesiapan kerja harian secara subyektif berdasarkan pengakuan partisipan. Data kesiapan kerja diplot pada grafik yang menunjukkan perbedaan tingkat kesiapan kerja dengan kelelahan kerja.

Waktu reaksi adalah salah satu indikator kelelahan syaraf dan indikator kinerja syaraf yang valid dan handal [21], [22]. Waktu reaksi adalah waktu yang diperlukan oleh partisipan untuk merespon stimulus yang muncul dengan satuan milisekon. Stimulus berbentuk gambar yang muncul dengan interval yang acak selama 3 menit. Waktu reaksi yang lambat, yaitu lebih dari 355 milisekon, menunjukkan adanya penurunan atensi sebagai bentuk gejala adanya kelelahan [21]. Semakin banyak waktu reaksi yang lambat, maka seseorang dikatakan semakin lelah. Teknik PVT (Psychomotor Vigilance Task) sudah banyak digunakan untuk mengukur kelelahan kerja, misalnya pada pekerja tambang [23], [24], teknisi 
yang bekerja pada saat shift malam [25], dan lain sebagainya. Kelelahan kerja dapat menyebabkan penurunan kemampuan mengolah informasi, dan penurunan kemampuan untuk bereaksi ketika berada dalam keadaan bahaya, sehingga kecelakaan kerja tidak dapat terhindarkan [26].

\section{HASIL DAN PEMBAHASAN}

Studi literatur secara sistematis menghasilkan kesimpulan bahwa terdapat tujuh faktor yang berkonstribusi terhadap kesiapan kerja, yaitu faktor konsumsi makanan, faktor waktu perjalanan, faktor kecukupan tidur, faktor adanya atau tidaknya gangguan siklus sirkadian, faktor individu, faktor lingkungan kerja, dan faktor kesehatan.

Faktor-faktor tersebut diseleksi ulang berdasarkan kesesuaian dengan kondisi riil. Faktor- faktor lain seperti faktor konsumsi makanan, faktor waktu perjalanan, faktor lingkungan kerja, dianggap sebagai faktor yang dapat dikendalikan, karena asumsi sebagai berikut: faktor konsumsi makanan diasumsikan adalah terkendali, karena semua pekerja mendapatkan jenis makanan yang sama. Faktor waktu perjalanan diasumsikan sama, karena perusahaan biasanya menyediakan angkutan karyawan, atau pada perusahaan pertambangan biasanya menyediakan tempat penginapan bagi para pekerja di dekat lokasi eksplorasi. Faktor lingkungan kerja diasumsikan adalah sama bagi pekerja di perusahaan yang sama. Faktor kesehatan diasumsikan sama, karena perusahaan biasanya menjalankan tes kesehatan ketika melakukan rekrutasi pekerja. Faktor konsumsi makanan, faktor lingkungan kerja, faktor waktu perjalanan, dan faktor kesehatan merupakan faktor-faktor yang diasumsikan tidak berubah dalam tempo harian. Peneliti berpendapat bahwa terdapat tiga faktor saja yang dapat berubah secara harian, sehingga cocok dijadikan sebagai faktor-faktor yang berpengaruh terhadap kesiapan kerja harian.

Model matematis yang dikembangkan dalam penelitian ini merupakan model untuk menghitung Indeks Kesiapan Kerja Harian. Indeks tersebut dikembangkan untuk menentukan apakah seseorang berada dalam kondisi siap bekerja atau tidak setiap hari. Indeks Kesiapan Kerja Harian dapat digunakan untuk menentukan apakah seseorang diizinkan untuk bekerja atau tidak. Indeks tersebut dibuat berdasarkan model konseptual, terutama pada konstruk kesiapan kerja harian yang dipengaruhi oleh faktor kecukupan tidur, faktor gangguan siklus sirkadian, dan faktor individu.

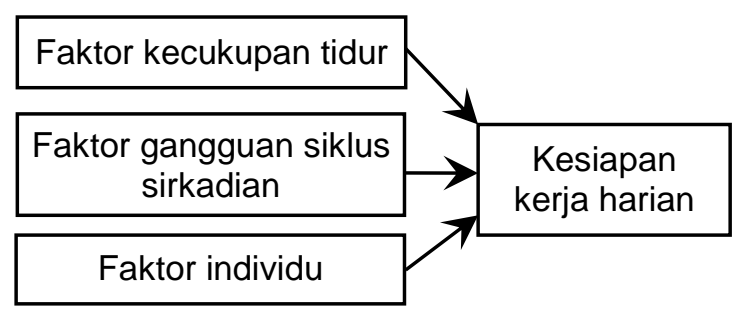

Gambar 4. Faktor-faktor yang berkonstribusi terhadap kesiapan kerja harian

\section{Kerangka Model Matematis}

Indeks Kesiapan Kerja Harian akan dikembangkan dalam persamaan matematis. Peneliti menyimpulkan dari studi literatur bahwa kesiapan kerja harian merupakan fungsi dari faktor individu, faktor kecukupan tidur, dan faktor gangguan siklus sirkadian.

$I K H=f\{(F I),(F K T),(F G S)\}$

Keterangan

IKH : Indeks Kesiapan Kerja Harian

FI : Faktor Individu

FKT : Faktor Kecukupan Tidur

FGS : Faktor Gangguan Siklus Sirkadian

Ukuran kesiapan kerja yang dapat digunakan secara sementara adalah ukuran subyektif, yaitu mengukur tingkat kesiapan kerja harian berdasarkan persepsi dari pekerja. Tingkat kesiapan kerja dapat diukur secara subyektif pertanyaan sebagai berikut: "Bagaimana Saudara menilai tingkat kesiapan fisik Saudara sendiri?". Partisipan diminta untuk menjawab pertanyaan tersebut, dengan lima pilihan skala, yaitu high, good, average, fair, low [27]. Lima skala tersebut dimodifikasi dengan cara menerjemahkan ke dalam bahasa Indonesia, kemudian menambahkan persentase. Skala tersebut dirubah menjadi istimewa (100\%), baik (75\%), sedang (50\%), cukup (25\%), dan buruk $(0 \%)$. Perubahan tersebut bertujuan untuk mendapatkan skala yang dapat dipahami oleh partisipan, sekaligus mendapatkan skala penilaian dengan interval yang sama. Ukuran ini masih memiliki kelemahan dari unsur subyektivitas dari partisipan dalam menjawabnya. Oleh karena itu, ukuran obyektif 
untuk menghitung indeks kesiapan kerja perlu dikembangkan. Ukuran subyektif dan ukuran obyektif akan dibandingkan untuk mencari tahu apakah terdapat korelasi yang kuat diantara kedua ukuran kesiapan kerja tersebut. Korelasi yang kuat menandakan bahwa model matematis yang dikembangkan dapat lebih dipercaya untuk dijadikan ukuran kesiapan kerja secara obyektif.

Faktor Individu (FI) didefinisikan sebagai nilai persentase yang menunjukkan perbandingan antara kemampuan individu untuk menghirup oksigen maksimum, dibandingkan dengan kemampuan terbaik suatu populasi tertentu. Populasi tersebut disesuaikan dengan konteks aktivitas pekerjaan yang sedang diteliti. Populasi yang dimaksud dalam penelitian ini adalah populasi pekerja tambang. Kemampuan pekerja tambang terbaik yang pernah dicatat sebesar 54 $\mathrm{ml} / \mathrm{Kg} . \min$ [28]. Kemampuan individu dalam menghirup oksigen dihitung berdasarkan estimasi denyut jantung [29]. Estimasi denyut jantung maksimum dihitung berdasarkan pendekatan usia [30].

$$
\begin{aligned}
& F I=\left(V O_{2} \text { maks individu } / V O_{2} \text { maks terbaik }\right) * 100 \% \\
& \mathrm{VO}_{2 \text { maks individu }}=15 \mathrm{~B}\left(H \mathrm{R}_{\text {maks }} / H R_{\text {ist }}\right) \\
& H R_{\text {maks }}=207-0,7 \mathrm{~A}
\end{aligned}
$$

\section{Keterangan}

FI : Faktor Individu (\%)

$\mathrm{VO}_{2 \text { maks individu }}$ :Kemampuan individu menghirup oksigen maksimum (ml/Kg.min)

$\mathrm{VO}_{2}$ maks terbaik :Kemampuan salah satu anggota populasi terbaik untuk menghirup oksigen maksimum ( $\mathrm{ml} / \mathrm{kg} \mathrm{min}$ ). $\mathrm{VO}_{2 \max }$ terbaik penambang adalah $54 \mathrm{ml} / \mathrm{Kg}^{\star} \min [28]$

$H R_{\text {maks }}$ : Denyut jantung maksimum (bpm)

$H R_{\text {ist }} \quad$ : Denyut jantung ketika beristirahat (bpm)

A : Usia (tahun)

$B \quad$ : Berat badan $(\mathrm{Kg})$

Faktor kecukupan tidur (FKT) diartikan sebagai nilai persentase yang memperlihatkan perbandingan antara total waktu tidur dengan waktu tidur ideal. Total waktu tidur dapat dihitung dengan alat jam pintar, dengan satuan jam. Waktu tidur ideal adalah 7,5 jam, yang diketahui berdasarkan penelitian dari Ferrara dan Gennaro [31].
$F K T=(T W T / 7,5) * 100 \%$

Keterangan

FKT : Faktor Kecukupan Tidur (\%)

TWT : Total Waktu Tidur (jam)

Faktor gangguan siklus sirkadian (FGS) dirumuskan sebagai nilai seratus persen dikurangi dengan nilai peningkatan risiko kecelakaan kerja. Nilai relatif peningkatan risiko kecelakaan kerja diperoleh dari hasil penelitian Folkard dan Tucher [10]. Hasil penelitian tersebut menyatakan bahwa ada peningkatan risiko kecelakaan kerja pada shift kerja sore dan shift kerja malam. Peningkatan risiko shift kerja sore adalah $18,3 \%$ lebih besar dari pada shift kerja pagi. Risiko kecelakaan shift kerja malam adalah $30,4 \%$ lebih besar daripada shift kerja pagi.

$F G S=(100 \%-R)$

Keterangan

FGS : Faktor Gangguan Siklus Sirkadian

$R \quad$ : Nilai risiko kecelakaan kerja relatif

\section{Model Matematis}

Model matematis yang diusulkan dalam penelitian ini adalah Indeks Kesiapan Kerja Harian, dengan mempertimbangkan faktor individu, faktor gangguan siklus sirkadian, dan faktor kecukupan tidur. Model matematis yang diajukan menjadi rumus perhitungan indeks kesiapan kerja dapat dilihat pada Persamaan 7.

$$
\begin{aligned}
I K H=\left\{\left[15 B(207-0,7 A) / H R_{\text {ist }}\right] / 54^{*} 100 \%\right\} * \\
\\
{\left[(T W T / 7,5)^{*} 100 \%\right] *(100 \%-R) }
\end{aligned}
$$

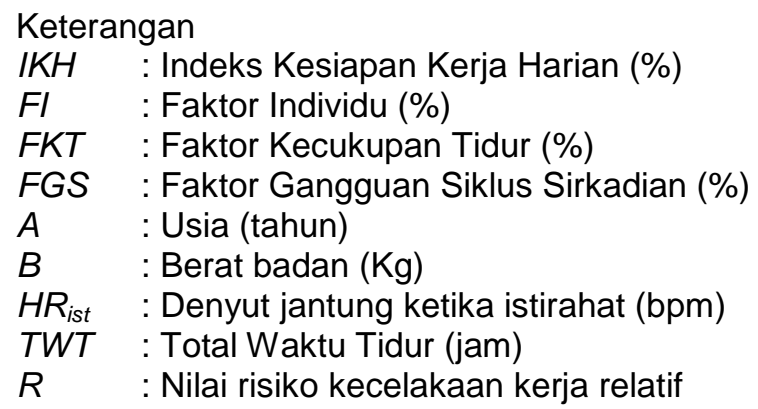

Kesiapan kerja harian dapat dihitung berdasarkan model matematis yang diajukan dalam penelitian ini. Model matematis tersebut dapat digunakan untuk menentukan apakah seorang pekerja dalam kondisi siap bekerja atau tidak. Model tersebut perlu untuk divalidasi. Validasi model dilakukan dengan cara eksperimen. Eksperimen perlu dilakukan untuk mengetahui hubungan antara variabel-variabel 
yang memengaruhi kesiapan kerja dengan Indeks Kesiapan Kerja Harian yang telah dikembangkan. Selain itu, eksperimen juga perlu dilaksanakan untuk mengetahui hubungan antara Indeks Kesiapan Kerja Harian dengan variabel kelelahan kerja.

Hasil pengukuran yang didapatkan adalah waktu tidur, berat badan, usia, dan tingkat kesiapan kerja secara subyektif. Lima puluh persen partisipan mendapatkan waktu tidur yang cukup, yaitu selama 7,5 jam. Sedangkan, setengah partisipan yang lain mengalami kekurangan waktu tidur. Setengah partisipan mengakui bahwa dirinya memiliki tingkat kesiapan kerja yang rendah, yaitu $50 \%$.

Tabel 1.Data waktu tidur, denyut jantung ketika istirahat, berat badan, dan tingkat kesiapan kerja secara subyektif

\begin{tabular}{|c|c|c|c|c|c|c|}
\hline $\begin{array}{l}\text { Partis } \\
\text { ipan }\end{array}$ & $\begin{array}{c}\text { Total } \\
\text { Waktu } \\
\text { tidur }\end{array}$ & $\begin{array}{l}\text { Shift } \\
\text { Kerja }\end{array}$ & $\begin{array}{c}\text { Denyut } \\
\text { Jantung } \\
\text { ketika } \\
\text { Istirahat }\end{array}$ & $\begin{array}{c}\text { Berat } \\
\text { Badan }\end{array}$ & Usia & $\begin{array}{c}\text { Ukuran } \\
\text { subyektif } \\
\text { tingkat } \\
\text { kesiapan } \\
\text { kerja (\%) }\end{array}$ \\
\hline 1 & 7.5 & Pagi & 53 & 70 & 33 & $90 \%$ \\
\hline 2 & 7.5 & Malam & 59 & 70 & 26 & $75 \%$ \\
\hline 3 & 5 & Pagi & 65 & 70 & 33 & $50 \%$ \\
\hline 4 & 4 & Malam & 64 & 75 & 38 & $50 \%$ \\
\hline
\end{tabular}

Tabel 2. Perhitungan Indeks Kesiapan Kerja Harian

\begin{tabular}{ccccc}
\hline $\begin{array}{c}\text { Partisi } \\
\text { pan }\end{array}$ & $\begin{array}{c}\text { Faktor } \\
\text { Individu }\end{array}$ & $\begin{array}{c}\text { Faktor } \\
\text { Kecukupan } \\
\text { Tidur }\end{array}$ & $\begin{array}{c}\text { Faktor } \\
\text { Gangguan } \\
\text { Siklus } \\
\text { Sirkadian }\end{array}$ & $\begin{array}{c}\text { Indeks } \\
\text { Kesiapan } \\
\text { Kerja } \\
\text { Harian } \\
\text { (IKH) }\end{array}$ \\
\hline 1 & $96 \%$ & $100 \%$ & $100 \%$ & $96 \%$ \\
2 & $89 \%$ & $100 \%$ & $70 \%$ & $62 \%$ \\
3 & $79 \%$ & $67 \%$ & $100 \%$ & $52 \%$ \\
4 & $78 \%$ & $53 \%$ & $70 \%$ & $29 \%$ \\
\hline
\end{tabular}

Korelasi antara pengukuran Kesiapan Kerja Harian berdasarkan pengukuran subyektif, dan pengukuran berdasarkan model matematis. Berdasarkan korelasi rho spearman, hubungan antara Indeks Kesiapan Kerja Harian dan pengukuran tingkat kesiapan kerja diketahui sebagai hubungan positif dan sangat kuat, dengan nilai 0,949 . Korelasi ini menandakan bahwa Indeks Kesiapan Kerja Harian memiliki dasar yang kuat untuk digunakan lebih lanjut dalam proses penelitian ini, karena hasil pengukuran indeks tersebut memiliki kesesuaian yang kuat dengan kesiapan kerja yang dirasakan oleh partisipan.

Hasil eksperimen pendahuluan berikutnya adalah pengukuran kelelahan kerja dengan pendekatan waktu reaksi, setiap dua jam. Data tersebut ditampilkan pada Gambar 5. Hasil pengukuran menunjukkan kecenderungan bahwa partisipanpartisipan yang memiliki nilai Indeks Kesiapan Kerja Harian (IKH) di bawah $60 \%$ akan mengalami kelelahan hingga ambang batasnya. Kelelahan tersebut terjadi pada saat pertengahan jam kerja. Pekerja yang terpapar kelelahan merupakan pekerja yang berisiko mengalami kecelakaan kerja. Partisipan yang memiliki nilai IKH lebih besar dari $60 \%$ cenderung dapat mengatasi rasa lelah, sehingga dapat bekerja dengan baik hingga jam kerja selesai.

Semakin tinggi indeks kesiapan kerja harian, maka semakin kecil kemungkinan pekerja mengalami kelelahan pada saat jam kerja. Demikian pula sebaliknya, semakin rendah indeks kesiapan kerja harian, maka semakin besar kemungkinan pekerja terpapar kelelahan kerja. Nilai $60 \%$ merupakan nilai indeks kesiapan kerja minimum yang dapat digunakan sebagai nilai ambang batas penilaian bahwa pekerja layak bekerja.

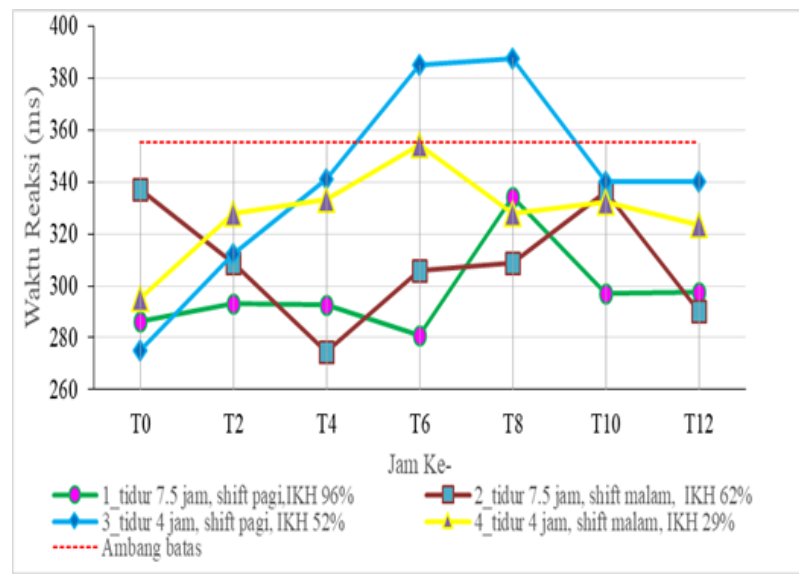

Gambar 5. Plot data waktu reaksi berdasarkan Indeks Kesiapan Kerja Harian.

\section{KESIMPULAN}

Indeks kesiapan kerja harian telah berhasil dikembangkan untuk menilai bahwa seseorang layak bekerja atau tidak layak. Indeks kesiapan kerja harian dihitung berdasarkan faktor-faktor yang didapatkan dari studi literatur secara 
sistematis. Faktor-faktor yang diyakini mempengaruhi kesiapan kerja harian adalah faktor kecukupan tidur, faktor siklus sirkadian, dan faktor individu. Rumus perhitungan indeks kesiapan kerja adalah ditampilkan pada Persamaan VII. Indeks kesiapan kerja harian memiliki korelasi yang kuat dengan pengukuran kesiapan kerja secara subyektif. Hal tersebut menunjukkan bahwa pengukuran indeks kesiapan kerja harian dapat dipercaya, karena memiliki kemiripan dengan perasaan kesiapan kerja yang dirasakan oleh pekerja. Indeks kesiapan kerja harian yang rendah menunjukkan bahwa pekerja dapat mengalami kelelahan pada saat jam kerja. Kelelahan kerja dapat memicu adanya kecelakaan kerja. Nilai $60 \%$ merupakan nilai indeks kesiapan kerja minimum yang dapat digunakan sebagai nilai ambang batas kelayakan.

\section{DAFTAR PUSTAKA}

[1] BPJS Ketenagakerjaan, "Laporan Berkelanjutan 2013, Penerapan tata kelola berkelanjutan," 2013.

[2] BPJS Ketenagakerjaan, "Resume Laporan Pengelolaan Program (Audited) 2015," 2015.

[3] S. Buranatrevedh, "Occupational Safety and Health Management among Five ASEAN Countries: Thailand, Indonesia, Malaysia, Philippines, and Singapore," J. Med. Assoc. Thail., vol. 98, no. 2, pp. 6469, 2015.

[4] R. B. Ward, "Revisiting Heinrich's law," Chemeca 2012 Qual. life through Chem. Eng. 23-26 Sept. 2012, Wellington, New Zeal., pp. 1179-1187, 2012.

[5] R. Whittingham, The blame machine: Why human error causes accidents. Oxford: Elsevier Butterworth-Heinemann., 2004.

[6] C. D. Reese, Occupational health and safety management: a practical approach, 2nd ed. Boca Raton: CRC Press, 2008.

[7] F. A. Manuele, "Reviewing Heinrich: Dislodging two myths from the practice of safety," Prof. Saf., vol. 56, no. 10, pp. 5261, 2011.

[8] Y. A. Elsayed, M. A. Al-Zahrani, and M. M. Rashad, "Factors affecting mental fitness for work in a sample of mentally ill patients," Int. J. Ment. Health Syst., vol. 3, no. 1, pp. 1-9, 2009.

[9] C. Serra, M. C. Rodriguez, G. L. Delclos, M. Plana, L. I. Gómez López, and F. G. Benavides, "Criteria and methods used for the assessment of fitness for work: a systematic review.," Occup. Environ.
Med., vol. 64, no. 5, pp. 304-312, 2007.

[10] S. Folkard and P. Tucker, "Shift work safety and productivity," Occup. Med. (Chic. III)., vol. 53, pp. 95-101, 2003.

[11] J. S. Boschman, C. T. J. Hulshof, M. H. W. Frings-Dresen, and J. K. Sluiter, "Improving fit to work assessments for rail safety workers by exploring work limitations," Int. Arch. Occup. Environ. Health, vol. 89, no. 5, pp. 803-811, 2016.

[12] D. Merkel, S. Moshe, O. Tal, and A. Eldad, "The fitness-for-work evaluation of a young patient with essential thrombocythemia," Acta Haematol, vol. 104, no. 1, pp. 38-41, 2000.

[13] T. M. Fraser, Fitness for work: The role of physical demands analysis and physical capacity assessment. London: Taylor \& Francis London., 1992.

[14] R. C. Blink and J. Schreibstein, "Fitnessfor-duty evaluation: Walking the medicallegal tightrope," J. Chem. Heal. Saf., vol. 14, no. 2, pp. 9-13, 2007.

[15] S. Bahn, "Workplace hazard identification and management: The case of an underground mining operation," Saf. Sci., vol. 57, pp. 129-137, 2013.

[16] B. Hanman, "The evaluation of physical ability," N. Engl. J. Med., vol. 258, no. 20, pp. 986-993, 1958.

[17] C. Pelissier, L. Fontana, and F. Chauvin, "Factors influencing return to work after illness in France," Occup. Med. (Chic. III)., vol. 64, no. 1, pp. 56-63, 2013.

[18] C. Sargent, D. Darwent, S. A. Ferguson, and G. D. Roach, "Can a simple balance task be used to assess fitness for duty?," Accid. Anal. Prev., vol. 45, pp. 74-79, 2012.

[19] D. Dawson and K. McCulloch, "Managing fatigue: It's about sleep," Sleep Med. Rev., vol. 9, no. 5, pp. 365-380, 2005.

[20] F. Espitia, J. Sánchez, and E. Galvis, "Systematic Literature Review of the Implementation of Knowledge Codification Process," in European Conference on Knowledge Management, 2016, p. 1111.

[21] M. Basner, D. Mollicone, and D. F. Dinges, "Validity and sensitivity of a brief psychomotor vigilance test ( PVT-B ) to total and partial sleep deprivation," Acta Astronaut., vol. 69, pp. 949-959, 2011.

[22] N. Goel, H. Rao, J. S. Durmer, and D. F. Dinges, "Neurocognitive consequences of sleep deprivation," in Seminars in neurology, 2009, vol. 29, no. 4, p. 320.

[23] S. A. Ferguson, D. J. Kennaway, A. Baker, N. Lamond, and D. Dawson, 
"Sleep and circadian rhythms in mining operators : Limited evidence of adaptation to night shifts," Appl. Ergon., vol. 43, no. 4, pp. 695-701, 2012.

[24] G. Legault, A. Clement, G. P. Kenny, S. Hardcastle, and N. Keller, "Cognitive consequences of sleep deprivation , shiftwork, and heat exposure for underground miners," Appl. Ergon., vol. 58, pp. 144-150, 2017.

[25] F. V. Narciso, J. A. Barela, S. A. Aguiar, A. N. S. Carvalho, S. Tufik, and M. T. De Mello, "Effects of shift work on the postural and psychomotor performance of night workers," PLoS One, vol. 11, no. 4, pp. 1-11, 2016.

[26] G. M. H. Swaen and L. G. P. M. Van Amelsvoort, "Fatigue as a risk factor for being injured in an occupational accident: results from the Maastricht Cohort Study," Occup. Environ. Med., vol. 60, pp. 88-92, 2003.

[27] K. H. Obling, A.-L. S. Hansen, K. Overgaard, K. Normann, A. Sandbaek, and H. T. Maindal, "Association between self-reported and objectively measured physical fitness level in a middle-aged population in primary care," Prev. Med. reports, vol. 2, pp. 462-466, 2015.

[28] K. Rodahl, The Physiology of Work. London: Taylor \& Francis, 2005.

[29] N. Uth, H. Sørensen, K. Overgaard, and P. K. Pedersen, "Estimation of VO2max from the ratio between HRmax and HRrest - The heart rate ratio method," Eur. J. Appl. Physiol., vol. 91, no. 1, pp. 111-115, 2004.

[30] R. L. Gellish, B. R. Goslin, R. E. Olson, A. Mcdonald, G. D. Russi, and V. K. Moudgil, "Longitudinal Modeling of the Relationship between Age and Maximal Heart Rate," Med. Sci. Sports Exerc., vol. 39, no. 5, pp. 822-829, 2007.

[31] M. Ferrara and L. De Gennaro, "How much sleep do we need?," Sleep Med. Rev., vol. 5, pp. 155-179, 2001. 